\title{
Stuck in painful time: perception of time by individuals with eating disorders depending on their mood
}

\author{
Uwięzieni w bolesnym czasie: postrzeganie czasu przez osoby \\ z zaburzeniami odżywiania a ich nastrój
}

\author{
1 Institute of Psychology, Faculty of Christian Philosophy, Cardinal Stefan Wyszyński University, Warsaw, Poland \\ 2"Drzewo życia"Foundation, Malawa, Poland \\ 'Instytut Psychologii, Wydział Filozofii Chrześcijańskiej, Uniwersytet Kardynała Stefana Wyszyńskiego, Warszawa, Polska \\ ${ }^{2}$ Fundacja „Drzewo życia”, Malawa, Polska
}

Correspondence: Małgorzata Starzomska-Romanowska, Institute of Psychology, Faculty of Christian Philosophy, Cardinal Stefan Wyszyński University in Warsaw, Wóycickiego 1/3, building 14, 01-938 Warsaw, Poland

\begin{abstract}
Introduction: Eating disorders still pose a formidable challenge to health care professionals. The suffering of eating-disordered individuals may be profound, with the main contributing factors being low self-esteem, guilt and depression, a sense of hopelessness, and loneliness. The objective of the study was to determine how patients with eating disorders perceive time, and in particular whether their experience of time differs from that of healthy individuals. Another goal was to examine the relationship between the mood of the subjects and their time perspective. Materials and methods: The subjects were 30 women with eating disorders and 30 age-matched healthy female controls. The three measures applied were: the Time Metaphors Questionnaire by Małgorzata Sobol-Kwapińska, the Time Perspective Inventory by Philip Zimbardo, and the UWIST Mood Adjective Checklist (UMACL) by Gerald Matthews et al. Results: As expected, statistical analyses revealed that women with eating disorders were characterised by a more negative perception of time than healthy subjects. The study also confirmed the expected correlations between positive and negative time perceptions and mood. Conclusion: The results appear to have a considerable scholarly and practical value, and should be used in the psychotherapy of eating-disordered individuals focusing on existential aspects, including in particular topics regarding the experience of time by sufferers.
\end{abstract}

Keywords: perception of time, eating disorders, psychotherapy

Streszczenie Wstęp: Zaburzenia odżywiania nadal stanowią poważne wyzwanie dla służby zdrowia. Cierpienie jednostek z zaburzeniami odżywiania może przybierać duże nasilenie, przy czym głównymi ich komponentami są niska samoocena, poczucie winy i depresja, odczucia beznadziejności i samotności. Celem badania była odpowiedź na pytanie, jak chore z zaburzeniami odżywiania postrzegają czas, w szczególności czy doświadczanie czasu różni je od zdrowych kobiet. Ponadto celem badania było zbadanie związku między nastrojem badanych a postrzeganiem czasu. Materiał i metoda: Przebadano 30 kobiet z zaburzeniami odżywiania i 30 zdrowych kobiet tworzących grupę kontrolną dopasowanych wiekiem do grupy klinicznej. Zastosowano trzy narzędzia: Kwestionariusz Metafory Czasu autorstwa Małgorzaty Sobol-Kwapińskiej, Inwentarz Perspektyw Postrzegania Czasu autorstwa Philipa Zimbardo i Przymiotnikową Skalę Nastroju autorstwa Geralda Matthewsa i wsp. Wyniki: Analizy statystyczne zgodnie z przewidywaniami potwierdziły, że kobiety z zaburzeniami odżywiania cechuje bardziej negatywne postrzeganie czasu niż zdrowe kobiety. Wykazano także zgodnie z oczekiwaniami korelacje między pozytywnie i negatywnie nacechowanym postrzeganiem czasu a nastrojem. Wnioski: Uzyskane wyniki wydają się mieć dużą wartość merytoryczno-praktyczną i powinny być wykorzystane jako ważny element interwencji psychoterapeutycznej u osób z zaburzeniami odżywiania zorientowanej na egzystencjalne aspekty tej grupy chorób, w tym szczególnie tematy dotyczące doświadczania czasu przez osoby chore.

Słowa kluczowe: zaburzenia odżywiania, postrzeganie czasu, psychoterapia 


\section{INTRODUCTION}

$\mathrm{D}$ espite considerable research efforts, eating disorders (the most widespread ones being anorexia and bulimia nervosa), still pose a formidable challenge to health care professionals (American Psychiatric Association, 2013). Noteworthy, a major body of research has been devoted to the existential aspects of eating disorders (Gans and Gunn, 2003; Lemma-Wright, 1994), focusing primarily on the identity of the affected individuals, including ego-syntonicity, which is the patients' belief that the disorder (e.g. extreme thinness) is a prerequisite for their personal self-fulfilment and happiness (Amianto et al., 2016; Bulik and Kendler, 2000; Lamoureux and Bottorff, 2005; Rieger and Touyz, 2006; Roncero et al., 2013). The suffering of eating-disordered individuals may be profound, with the main contributing factors being low self-esteem, guilt and depression, a sense of hopelessness, and loneliness (Lemma-Wright, 1994; Manley and Leichner, 2003). For individuals with anorexia nervosa, the illness is a trap: even if they want to follow a path to recovery, they fear their existence would crumble without the disorder. In addition, as that fear diminishes with declining ego-syntonicity after the "honeymoon phase" is over, anorexic patients begin to despair that their bodies will never return to the pre-illness state, and that they have wasted the best years of their life. Consequently, they are likely to give up their struggle to regain health and normal life, sometimes applying for palliative care (Draper, 2000). It should be noted that eating disorders are chronic conditions which are not fully treatable, with the sufferers being haunted by the lingering spectre of relapse (Mander et al., 2013; Starzomska et al., 2020; Wildes et al., 2017). One of the numerous questions concerning the existential aspects of the functioning of persons with eating disorders is, beyond any doubt, the question of their perception of time.

Subjectively experienced time has been of long-standing interest to psychological research and has come to be known as psychological time (Klamut, 2010; Lens, 1994; Zdybek, 2012). It can also be defined as both conscious and unconscious experience of time (Zdybek, 2012), as well as its cognitive, behavioural, and emotional consequences (Nosal, 2000; Popiołek, 2010). Research into existential time focuses on such issues as temporal perspectives, orientations, and attitudes (Nosal and Bajcar, 2004; Zając-Lamparska, 2011). According to Zimbardo and Boyd (1999) the temporal perspective is one of the predominant factors affecting human thoughts, feelings, and actions. In turn, one's temporal orientation denotes one's preferred temporal perspective - past, present, or future. Zimbardo and Boyd (1999) proposed five time-perception dimensions: Past-Negative, Past-Positive, Present-Fatalistic, Present-Hedonistic, and Future; additionally they also suggested a transcendental future time perspective. Each temporal orientation implies a certain mindset translating into daily life choices. A temporal attitude can be defined as an individual's views on time itself and its dimensions (Nosal and Bajcar, 2004). According to Sobol-Kwapińska (2007), who alternatively calls temporal attitudes "temporal orientations," they consist of two aspects: the focus of one's attention, feelings, and behaviours within a given time perspective, and the evaluation of time by attributing to it positive or negative qualities, attaching (or not) importance, as well as perceiving it as long or short, coherent or incoherent. Furthermore, Sobol-Kwapińska (2008) has shown that a valuable source of information about time evaluation is afforded by metaphors, which serve as convenient devices for talking about such a complex and elusive phenomenon as time.

The authors of this paper are particularly interested in the following question: given the severe existential suffering of individuals with eating disorders, who often regret the past, agonise in the present, and do not see hope for the future, how do such individuals actually perceive time? (Nosal and Bajcar, 2004; Popiołek, 2010). How do their death-related thoughts and occasional confrontations with death translate into their experience of time - is it painful? It seems that answering this question may be crucially important, especially since, according to the knowledge of the paper's authors, no scientific studies on this subject have been performed so far.

The objective of this study was to determine how individuals with eating disorders perceive time, and in particular whether their experience of time differs from that of healthy persons. Another aim was to investigate the relationship between the mood of the subjects and their time perception. First, it was expected that eating-disordered patients experience time as a rather aversive and unfriendly force marked with chaos and void, in contrast to healthy subjects, who were predicted to treat it as something more friendly, appreciating its subtleties and the significance of the moment (Hypothesis 1). Moreover, it was expected that individuals with eating disorders would exhibit a more negative temporal orientation, whether past or present, as compared to women without eating disorders, who would reveal more positive past, present, or future orientations (Hypothesis 2).

Finally, it was expected that one's mood would be associated with one's experience of time, that is, Tense Arousal would be correlated with a negative time perception, while Energetic Arousal and Hedonic Tone would be linked to a positive time perception (Hypothesis 3).

\section{MATERIALS AND METHODS}

The study encompassed 30 women with eating disorders (19 patients with anorexia nervosa and 11 patients with bulimia nervosa) and 30 age-matched women without eating disorders. Their sociodemographic data are given in Tab. 1 . The clinical group consisted of patients from the residential eating disorder therapeutic centre "Drzewo życia" in Malawa as well as some outpatient clinics in Poland; some of the patients were not being actively treated at the time of the study. The controls included psychology students from two Polish universities (the Cardinal Stefan Wyszyński University and the University of Finance and Management, both in Warsaw), as well as researchers and educators who volunteered for the study. 
The three measures applied in the study were:

- The Time Metaphors Questionnaire by Małgorzata SobolKwapińska. The measure consists of 95 items formulated as metaphors to describe ideas eliciting strong emotions (Sobol-Kwapińska, 2008, 2007). The subjects are asked to rate the items on a scale from 1 to 4 , depending on the degree to which a given metaphor is consistent with their perception of time. The items are grouped into three scales reflecting positive attitudes to time: Friendly Time (subdivided into two subscales: Constructive Time and Pleasant Time), Significance of the Moment, and Subtle Time, as well as four scales covering negative attitudes to time: Hostile Time (with three subscales: Finiteness of Time, Bitter Time, and Confusion in Time), Rapid Passage of Time, Wild Time, and Empty Time. The questionnaire reveals satisfactory reliability and validity (Sobol-Kwapińska, 2008).

- Time Perspective Inventory by Philip Zimbardo (Zimbardo and Boyd, 2009; see also Zimbardo and Boyd, 1999). The measure consists of 56 items which the respondents rate on a 5-point scale ranging from 1 (very uncharacteristic of me) to 5 (very characteristic of me). The questionnaire tests five time perspectives: 1) Past-Negative, 2) Past-Positive, 3) Present-Hedonistic, 4) Present-Fatalistic, and 5) Future. The Polish version of this instrument has been reported to have both good reliability and validity (Mażewski, 2005). In addition, the 10-item Transcendental Future Time Perspective Inventory was used (Zimbardo and Boyd, 2009).

- The UWIST Mood Adjective Checklist (UMACL) by Gerald Matthews et al. (1990; see also Goryńska, 2005). The instrument measures mood understood as an affective experience of a duration of at least several minutes; its three scales are Tense Arousal, Energetic Arousal, and Hedonic Tone. The UMACL consists of a list of 29 adjectives which the respondents rate in terms of applicability to their current mood on a 4-point scale from "definitely yes" to "definitely not." The reliability and validity of the Polish adaptation have been confirmed.

The study design was approved by the Ethics Committee at the Cardinal Stefan Wyszyński University in Warsaw (permit no. KEIB - 20/2017). All participants gave their informed consent, having been assured that the study was anonymous with the results used solely for research purposes.

Statistical analysis included the independent samples $t$-test, Mann-Whitney's U test, and Pearson's and Spearman's rank tests using Statistica software, version 5.1 for Windows.

\section{RESULTS}

\section{Sociodemographic data}

Tab. 1 gives the sociodemographic data of the subjects. The clinical and control groups did not differ significantly in terms of age or height. Obviously, significant differences were found in terms of weight and body mass index (BMI): women with eating disorders were much lighter and had a much lower BMI than women without eating disorders. The mean duration of the patient's eating disorder was 8.9 years.

\section{Intergroup comparisons and correlations}

In order to apply appropriate statistical tests, the studied variables were checked for normal distribution in both groups. It was found that only one variable in one group (Energetic Arousal in the control group) did not have normal distribution, and required the application of nonparametric tests, that is, Mann-Whitney's U tests and Spearman's rank test (only for correlations within the control group). In the remaining cases, the parametric tests used included the independent samples $t$-test and Pearson's test.

Tab. 2 presents inter-group differences in terms of experience of time and mood.

As can be seen from Tab. 2, in the Time Metaphors Questionnaire statistically significant differences were found between the eating-disordered group and the control group for the Hostile Time scale, including all of its three subscales: Finiteness of Time, Bitter Time, and Confusion in Time. Moreover, the clinical group differed statistically significantly from the controls in terms of the Empty Time scale and the Wild Time scale. As far as the Time Perspective Inventory is concerned, women with eating disorders scored significantly higher than women without eating disorders on the Past-Negative scale, and significantly lower on the Present-Hedonistic scale as well as the Past-Positive scale. Furthermore, women with eating disorders obtained higher scores (near statistical significance) on the Future scale.

Finally, the UMACL revealed significant differences between the two groups in terms of Hedonic Tone and Energetic Arousal, with eating-disordered women scoring lower than women without eating disorders on both of them.

\begin{tabular}{|l|c|c|c|c|c|c|c|}
\hline & $\begin{array}{c}\boldsymbol{M} \\
\text { (women with } \\
\text { eating disorders) }\end{array}$ & $\begin{array}{c}\text { (women with eating } \\
\text { disorders) }\end{array}$ & $\begin{array}{c}\text { SD } \\
\text { (women without } \\
\text { eating disorders) }\end{array}$ & $\begin{array}{c}\text { SD } \\
\text { (women without } \\
\text { eating disorders) }\end{array}$ & $\boldsymbol{t}$ & $\boldsymbol{d}$ & $\boldsymbol{p}$ \\
\hline Age & 26.88 & 5.82 & 24.27 & 6.49 & 1.64 & 58 & 0.100 \\
\hline Height & 166.2 & 5.6 & 166.9 & 5.9 & -0.54 & 58 & 0.590 \\
\hline Weight & 50.78 & 13.05 & 60.43 & 12.48 & -2.93 & 58 & $0.005^{*}$ \\
\hline BMI & 18.3 & 4.49 & 21.62 & 3.98 & -3.03 & 58 & $0.004^{*}$ \\
\hline Duration of disorder & 8.9 & 5.23 & - & - & - & - & - \\
\hline${ }^{*} p<0.01$ & \multicolumn{7}{|l|}{}
\end{tabular}




\begin{tabular}{|c|c|c|c|c|c|c|c|}
\hline & $\begin{array}{c}M / M e \\
\text { (women with } \\
\text { eating disorders) }\end{array}$ & $\begin{array}{c}\text { SD } \\
\text { (women with } \\
\text { eating disorders) }\end{array}$ & $\begin{array}{c}M / M e \\
\text { (women without } \\
\text { eating disorders) }\end{array}$ & $\begin{array}{c}\text { SD } \\
\text { (women without } \\
\text { eating disorders) }\end{array}$ & $t / Z$ & $d f$ & $p$ \\
\hline \multicolumn{8}{|c|}{ Scales and subscales of the Time Metaphors Questionnaire (subscales are given in italics) } \\
\hline Friendly Time & 5.1 & 2.04 & 4.53 & 2.24 & 1.02 & 58 & 0.310 \\
\hline Constructive Time & 5.4 & 2.01 & 5.0 & 2.43 & 0.69 & 58 & 0.490 \\
\hline Pleasant Time & 4.8 & 2.35 & 4.3 & 2 & 0.88 & 58 & 0.380 \\
\hline Hostile Time & 7.13 & 1.94 & 4.7 & 1.78 & 5.05 & 58 & $0.000^{* * *}$ \\
\hline Finiteness of Time & 6.8 & 2.09 & 4.53 & 1.94 & 4.35 & 58 & $0.000^{* * *}$ \\
\hline Bitter Time & 7.3 & 1.86 & 4.97 & 1.97 & 4.71 & 58 & $0.000^{* * *}$ \\
\hline Confusion in Time & 7.0 & 1.95 & 5.1 & 1.92 & 3.81 & 58 & $0.000^{* * *}$ \\
\hline Empty Time & 5.23 & 3.52 & 3.23 & 2.36 & 2.58 & 58 & $0.010^{*}$ \\
\hline Subtle Time & 4.87 & 2.09 & 4.6 & 2.28 & 0.47 & 58 & 0.640 \\
\hline Wild Time & 6.03 & 1.69 & 4.8 & 2.2 & 2.43 & 58 & $0.020^{*}$ \\
\hline Significance of the moment & 5.63 & 2.66 & 6.33 & 2.72 & -1.01 & 58 & 0.320 \\
\hline Rapid Passage of Time & 6.0 & 2.26 & 5.4 & 1.94 & 1.1 & 58 & 0.270 \\
\hline \multicolumn{8}{|c|}{ Scales of the Time Perspective Inventory } \\
\hline Past-Negative time perspective & 3.61 & 0.86 & 2.64 & 0.78 & 4.55 & 58 & $0.000^{* * *}$ \\
\hline Present-Hedonistic time perspective & 3.13 & 0.59 & 3.58 & 0.72 & -2.67 & 58 & $0.009^{* *}$ \\
\hline Future time perspective & 3.73 & 0.6 & 3.45 & 0.59 & 1.79 & 58 & $0.080 \#$ \\
\hline Past-Positive time perspective & 2.91 & 0.87 & 3.93 & 0.47 & -5.61 & 58 & $0.000 * * *$ \\
\hline Present-Fatalistic time perspective & 2.62 & 0.62 & 2.62 & 0.63 & 0.00 & 58 & 1.000 \\
\hline Transcendental Future time perspective & 3.32 & 0.88 & 3.68 & 0.81 & -1.65 & 58 & 0.100 \\
\hline \multicolumn{8}{|c|}{ Scales of the UWIST Mood Adjective Checklist (UMACL) } \\
\hline Hedonic Tone & 3.43 & 1.87 & 5.33 & 2.07 & -3.73 & 58 & $0.000^{* * *}$ \\
\hline Energetic Arousal & 3.0 & 2.09 & 5.0 & 1.95 & -3.21 & 58 & $0.001^{* *}$ \\
\hline Tense Arousal & 7.33 & 2.12 & 6.67 & 2.07 & 1.23 & 58 & 0.220 \\
\hline
\end{tabular}

Tab. 2. Differences between women with eating disorders and women without eating disorders in terms of experiencing time and mood

\begin{tabular}{|c|c|c|c|}
\hline $\begin{array}{l}\text { Scales and } \\
\text { subscales of the Time } \\
\text { Metaphors Questionnaire } \\
\text { and the Time Perspective Inventory }\end{array}$ & Hedonic Tone & Energetic Arousal & Tense Arousal \\
\hline Friendly Time & $r=0.21$ & $r=0.16$ & $r=0.10$ \\
\hline Constructive Time & $r=0.25$ & $r=0.21$ & $r=0.00$ \\
\hline Pleasant Time & $r=-0.07$ & $r=-0.02$ & $r=0.27$ \\
\hline Hostile Time & $r=-0.18$ & $r=-0.22$ & $r=0.06$ \\
\hline Finiteness of Time & $r=-0.01$ & $r=-0.19$ & $r=-0.12$ \\
\hline Bitter Time & $r=-0.11$ & $r=-0.09$ & $r=0.06$ \\
\hline Confusion in Time & $r=-0.34$ & $r=-0.24$ & $r=0.17$ \\
\hline Empty Time & $r=-0.47^{*}$ & $r=-0.63^{*}$ & $r=0.16$ \\
\hline Subtle Time & $r=-0.02$ & $r=-0.13$ & $r=0.12$ \\
\hline Wild Time & $r=0.08$ & $r=0.19$ & $r=0.17$ \\
\hline Significance of the Moment & $r=0.21$ & $r=0.06$ & $r=-0.19$ \\
\hline Rapid Passage of Time & $r=0.13$ & $r=0.20$ & $r=0.21$ \\
\hline Past-Negative time perspective & $r=-0.13$ & $r=-0.14$ & $r=0.17$ \\
\hline Present-Hedonistic time perspective & $r=0.41^{*}$ & $r=0.25$ & $r=-0.10$ \\
\hline Future time perspective & $r=-0.10$ & $r=0.02$ & $r=-0.10$ \\
\hline Past-Positive time perspective & $r=0.15$ & $r=0.06$ & $r=0.15$ \\
\hline Present-Fatalistic time perspective & $r=-0.24$ & $r=-0.44^{*}$ & $r=0.23$ \\
\hline Transcendental Future time perspective & $r=-0.10$ & $r=-0.19$ & $r=-0.06$ \\
\hline
\end{tabular}




\begin{tabular}{|c|c|c|c|}
\hline $\begin{array}{l}\begin{array}{l}\text { Scales and } \\
\text { subscales of the Time Metaphors } \\
\text { Questionnaire and the Time Perspective Inventory }\end{array} \\
\begin{array}{r}\text { Scales of the UWIST Mood } \\
\text { Adjective Checklist }\end{array}\end{array}$ & Hedonic Tone & Energetic Arousal & Tense Arousa \\
\hline Friendly Time & $r=0.35$ & rho $=0.35$ & $r=0.11$ \\
\hline Constructive Time & $r=0.33$ & rho $=0.31$ & $r=0.16$ \\
\hline Pleasant Time & $r=0.32$ & rho $=0.27$ & $r=0.00$ \\
\hline Hostile Time & $r=-0.39^{*}$ & $\mathrm{rho}=-0.23$ & $r=0.32$ \\
\hline Finiteness of Time & $r=-0.23$ & rho $=-0.15$ & $r=0.16$ \\
\hline Bitter Time & $r=-0.33$ & rho $=-0.06$ & $r=0.25$ \\
\hline Confusion in Time & $r=-0.46^{*}$ & rho $=-0.29$ & $r=0.30$ \\
\hline Empty Time & $r=-0.22$ & rho $=-0.33 \#$ & $r=0.01$ \\
\hline Subtle Time & $r=0.17$ & rho $=0.13$ & $r=0.12$ \\
\hline Wild Time & $r=-0.21$ & rho $=0.01$ & $r=0.38^{*}$ \\
\hline Significance of the Moment & $r=-0.01$ & rho $=0.01$ & $r=0.19$ \\
\hline Rapid Passage of Time & $r=-0.43^{*}$ & rho $=-0.01$ & $r=0.60^{*}$ \\
\hline Past-Negative time perspective & $r=-0.49^{*}$ & rho $=-0.27$ & $r=0.14$ \\
\hline Present-Hedonistic time perspective & $r=0.30$ & $\mathrm{rho}=0.42^{*}$ & $r=-0.15$ \\
\hline Future time perspective & $r=-0.17$ & rho $=-0.005$ & $r=0.18$ \\
\hline Past-Positive time perspective & $r=0.19$ & rho $=-0.17$ & $r=-0.04$ \\
\hline Present-Fatalistic time perspective & $r=-0.04$ & rho $=-0.16$ & $r=-0.00$ \\
\hline Transcendental Future time perspective & $r=-0.16$ & $\mathrm{rh}_{0}=-0.18$ & $r=0.13$ \\
\hline
\end{tabular}

Tab. 4. Correlations between the experience of time and mood in women without eating disorders

Tabs. 3 and 4 present correlations between time perspectives and mood in the clinical group and in the group of women without eating disorders, respectively.

Women with eating disorders exhibited a moderate negative correlation between Empty Time and Hedonic Tone, and a strong negative correlation between the former and Energetic Arousal.

Moreover, the clinical group revealed a moderate positive correlation between the Present-Hedonistic time perspective and Hedonic Tone, and a moderate negative correlation between the Present-Fatalistic perspective and Energetic Arousal.

The group of healthy women showed a weak negative correlation between Hedonic Tone and an experience of Hostile Time, as well as moderate negative correlations between the former and Confusion in Time, Rapid Passage of Time, and the Past-Negative time perspective. A moderate positive correlation was found between the Present-Hedonistic time perspective and Energetic Arousal, and a near-significant weak negative correlation between Empty Time and Energetic Arousal. Women without eating disorders also exhibited a weak positive correlation between Wild Time and Tense Arousal. Finally, a strong positive correlation was identified between Rapid Passage of Time and Tense Arousal.

\section{DISCUSSION}

As expected in Hypothesis 1 (which was partially confirmed), females with eating disorders differed significantly from wom- experiencing it as more hostile, and in particular more finite (destructive, bringing one closer to death, as expressed in the metaphor "time is a stairway leading to the grave"), bitter ("time is painful"), and confusing ("time is like woods in which everyone gets lost"). It is worth stressing here that, on the one hand, women with eating disorders experience intense anxiety over gaining weight and that, as a result of treatment, they will be deprived of the value that their illness is to them (cf. ego-syntonicity). On the other hand, their state of health is often in jeopardy. Understandably, therefore, they are afraid of the passage of time. Moreover, the sufferers often deal with depression and low self-esteem, and tend to be filled with sadness, anxiety, guilt, alienation, and hopelessness, which can be related to perceiving time as chaotic or empty.

As expected in Hypothesis 2 (partially confirmed), eating-disordered women exhibited a larger degree of the Past-Negative time perspective than women without eating disorders, who were in turn more likely to embrace the Present-Hedonistic and Past-Positive perspectives. Interestingly, as opposed to women without eating disorders, more women with eating disorders exhibited the Future time perspective (near statistical significance). This result may be explained in the following way: some patients may seek hope and strength for recovery from their chronic condition by looking to the future despite exhibiting a generally depressed mood and a bitter perception of the past. It seems that this manner of perceiving time, predominant in afflicted women, is associated with the fact that the "honeymoon phase," when sufferers are full of energy and optimism, is followed by a period of progressive cachexia, 
during which the sufferer - even if she/he wants to recover - is aware that she/he will never be perfectly healthy again. Looking back, she/he may regret having brought their body to such a state, and see their past as a series of failures.

Hypothesis 3 was also partially confirmed in that the experience of Empty Time by patients coincided with their reduced energy (Energetic Arousal) and a lesser ability to experience pleasure (Hedonic Tone), the Present-Hedonistic time perspective was accompanied by a greater openness to pleasure, and the Present-Fatalistic time perspective was associated with low Energetic Arousal. In turn, among women without eating disorders the perception of Hostile Time, Confusion in Time, a sense of Rapid Passage of Time, and the Past-Negative time perspective coincided with a low ability to experience pleasure. Moreover, Energetic Arousal was correlated positively with the Present-Hedonistic time perspective and negatively with Empty Time (the latter relationship was near-significant). Finally, a sense of temporal chaos and Rapid Passage of Time were accompanied by high Tense Arousal.

\section{CONCLUSIONS}

The obtained results not only corroborate the research hypotheses, but also have important theoretical and practical implications. First of all, they afford valuable insights into the inner world of eating-disordered patients, and in particular into the intimate dimension of their existence which is time experience. It has become clear that individuals with eating disorders perceive time more negatively than women without eating disorders, which is due to the suffering experienced by the former in relation to their serious chronic illnesses. The past cannot be mended, the present hurts, and the future appears obscure and threatening. Thus, eating-disordered individuals appear to be stuck (Gruber et al., 2012; Holman and Silver, 1998) in painful time. These findings of the study should be used as important elements in therapeutic interventions oriented toward the existential aspects of eating disorders.

\section{Conflict of interest}

The authors do not report any financial or personal connections with other persons or organisations which might negatively affect the contents of this publication and/or claim authorship rights to this publication.

\section{Funding/Support and role of the sponsor}

This research project was supported by a grant for maintaining research potential awarded by the Cardinal Stefan Wyszyński University in Warsaw, No. PBF-31/16.

\section{References}

American Psychiatric Association: Diagnostic and Statistical Manual of Mental Disorders, Fifth Edition. DSM-5. American Psychiatric Association, Arlington, VA 2013.

Amianto F, Northoff G, Abbate Daga G et al.: Is anorexia nervosa a disorder of the self? A psychological approach. Front Psychol 2016; 7: 849.
Bulik CM, Kendler KS: "I am what I (don't) eat": establishing an identity independent of an eating disorder. Am J Psychiatry 2000; 157: 1755-1760.

Draper H: Anorexia nervosa and respecting a refusal of life-prolonging therapy: a limited justification. Bioethics 2000; 14: 120-133.

Gans M, Gunn WB Jr: End stage anorexia: criteria for competence to refuse treatment. Int J Law Psychiatry 2003; 26: 677-695.

Goryńska E: Przymiotnikowa Skala Nastroju UMACL Geralda Matthewsa, A. Grahama Chamberlaina, Dylana M. Jonesa. Pracownia Testów Psychologicznych Polskiego Towarzystwa Psychologicznego, Warszawa 2005.

Gruber J, Cunningham WA, Kirkland T et al.: Feeling stuck in the present? Mania proneness and history associated with present-oriented time perspective. Emotion 2012; 12: 13-17.

Holman EA, Silver RC: Getting "stuck" in the past: temporal orientation and coping with trauma. J Pers Soc Psychol 1998; 74: 1146-1163.

Klamut R: Poziomy czasu psychologicznego a system osobowości. In: Popiołek K, Chudzicka-Czupała A (eds.): Czas w życiu człowieka. Wydawnictwo Uniwersytetu Śląskiego, Katowice 2010: 118-132.

Lamoureux MMH, Bottorff JL: "Becoming the real me": recovering from anorexia nervosa. Health Care Women Int 2005; 26: 170-188.

Lemma-Wright A: Starving to Live. The Paradox of Anorexia Nervosa. Central Book Publishing, London 1994.

Lens W: Odraczanie nagrody, samokontrola a przyszłościowa perspektywa czasowa. In: Januszewski A, Oleś P, Witkowski T (eds.): Wykłady z psychologii w KUL. Vol. 7, Redakcja Wydawnictw Katolickiego Uniwersytetu Lubelskiego, Lublin 1994: 297-308.

Mander J, Teufel M, Keifenheim K et al.: Stages of change, treatment outcome and therapeutic alliance in adult inpatients with chronic anorexia nervosa. BMC Psychiatry 2013; 13: 111.

Manley RS, Leichner P: Anguish and despair in adolescents with eating disorders: helping to manage suicidal ideation and impulses. Crisis 2003; 24: 32-36.

Matthews G, Jones DM, Chamberlain AG: Refining the measurement of mood: the UWIST Mood Adjective Checklist. Br J Psychol 1990; 81: 17-42.

Mażewski M: Adaptacja kwestionariusza ZTPI Zimbardo. Niepublikowana praca magisterska, Uniwersytet Śląski, Katowice 2005.

Nosal CS: Czas jako wymiar regulacji zachowania. In: Brzeziński J, Kowalik S (eds.): O różnych sposobach uprawiania psychologii. Wydawnictwo Zysk i Spółka, Poznań 2000: 106-130.

Nosal CS, Bajcar B: Czas psychologiczny: wymiary, struktura, konsekwencje. Wydawnictwo Instytutu Psychologii PAN, Warszawa 2004.

Popiołek K: Percepcja czasu - czas codzienny i czas życia. In: Popiołek K, Chudzicka-Czupała A (eds.): Czas w życiu człowieka. Wydawnictwo Uniwersytetu Śląskiego, Katowice 2010: 86-100.

Rieger E, Touyz S: An investigation of the factorial structure of motivation to recover in anorexia nervosa using the Anorexia Nervosa Stages of Change Questionnaire. Eur Eat Disord Rev 2006; 14: 269-275.

Roncero M, Belloch A, Perpiñá C et al.: Ego-syntonicity and ego-dystonicity of eating-related intrusive thoughts in patients with eating disorders. Psychiatry Res 2013; 208: 67-73.

Sobol-Kwapińska M: KMC - Kwestionariusz Metafory Czasu. Podręcznik. Pracownia Testów Psychologicznych Polskiego Towarzystwa Psychologicznego, Warszawa 2008.

Sobol-Kwapińska M: Żyć chwilą? Postawy wobec czasu a poczucie szczęścia. Wydawnictwo KUL, Lublin 2007.

Starzomska M, Rosińska P, Bielecki J: Chronic anorexia nervosa: patient characteristics and treatment approaches. Psychiatr Pol 2020; 54: 821-833.

Wildes JE, Forbush KT, Hagan KE et al.: Characterizing severe and enduring anorexia nervosa: an empirical approach. Int J Eat Disord 2017; 50: 389-397.

Zając-Lamparska L: Czas jako kryterium opisu oraz mechanizm regulacji funkcjonowania człowieka: problematyka czasu w psychologii. Przegląd Naukowo-Metodyczny. Edukacja dla Bezpieczeństwa 2011; 13 (4): 111-124.

Zdybek P: Rola orientacji temporalnej na teraźniejszość w wyjaśnianiu preferowanej strategii seksualnej. Acta Universitatis Lodziensis Folia Psychologica 2012; 16: 113-131.

Zimbardo PG, Boyd J: Paradoks czasu. PWN, Warszawa 2009.

Zimbardo PG, Boyd JN: Putting time in perspective: a valid, reliable individual-differences metric. J Pers Soc Psychol 1999; 77: 1271-1288. 